\title{
A day in the lives of older adults: what makes them happy?
}

\author{
Tina Kavčič $\check{c}^{*}$ and Andreja Avsec ${ }^{2}$ \\ ${ }^{1}$ Faculty of Education, University of Primorska, Slovenia \\ ${ }^{2}$ Department of Psychology, Faculty of Arts, University of Ljubljana, Slovenia
}

\begin{abstract}
The aim of the present study was to examine how older adults ( $N=84 ; 51$ females; aged 65 to 91 years) in Slovenia spend their time and what they experience throughout the day. The contribution of these activities and their experiences to participants' subjective well-being was also explored. Using the Day Reconstruction Method, the participants reported how much time during the preceding day they spent in different activities, the level of hedonia (presence of positive and absence of negative emotionality) and eudaimonia (meaning, focus, usefulness) experienced during each activity in the past day, and their general satisfaction with the day. In addition, they assessed their overall emotional, psychological, and social well-being. Vast individual differences in time-use and in subjective perceptions of various activities were revealed. Overall, certain activities were related to older adults' well-being, although it seems that subjective perceptions of activities are more important than activities themselves.
\end{abstract}

Keywords: late adulthood, Day Reconstruction Method, eudaimonic experiences, hedonic experiences, well-being

\section{Dan v življenju starejših odraslih: kaj jih osrečuje?}

\author{
Tina Kavčič ${ }^{*}$ in Andreja Avsec ${ }^{2}$ \\ ${ }^{1}$ Pedagoška fakulteta, Univerza na Primorskem \\ ${ }^{2}$ Oddelek za psihologijo, Filozofska fakulteta, Univerza v Ljubljani
}

Povzetek: Namen pričujoče študije je raziskati, kako slovenski starejši odrasli ( $N=84 ; 51$ žensk in 33 moških, starih od 65 do 91 let $)$ preživljajo svoj čas in kaj doživljajo preko naključnega dneva. Poleg tega je bil cilj preučiti tudi morebiten prispevek teh dejavnosti in njihovega doživljanja na subjektivno blagostanje starejših. Z uporabo Metode obnovitve dneva so udeleženci poročali, koliko časa $\mathrm{V}$ preteklem dnevu so se vključevali v posamezne dejavnosti, ocenili raven hedonskih (prisotnost pozitivnega in odsotnost negativnega čustvovanja) in eudaimonskih (smisel, osredotočenost, koristnost) izkušenj med vsako dejavnostjo ter ovrednotili splošno zadovoljstvo $\mathrm{s}$ tem dnevom. Udeleženci so nato poročali tudi o svojem splošnem čustvenem, psihološkem in socialnem blagostanju. Rezultati so pokazali ogromne medosebne razlike tako v rabi časa kot tudi v subjektivnem doživljanju različnih dejavnosti. Na splošno so se določene dejavnosti povezovale z blagostanjem starejših odraslih, čeprav rezultati nakazujejo, da je subjektivno doživljanje dejavnosti pomembnejše kot dejavnosti same.

Ključne besede: pozna odraslost, metoda obnovitve dneva, eudaimonske izkušnje, hedonske izkušnje, blagostanje

\footnotetext{
*Naslov/Address: izr. prof. dr. Tina Kavčič, Pedagoška fakulteta, Univerza na Primorskem, Cankarjeva 5, 6000 Koper, e-mail: tina.kavcic@pef.upr.si

Članek je licenciran pod pogoji Creative Commons Attribution 4.0 International licence. (CC-BY licenca).

The article is licensed under a Creative Commons Attribution 4.0 International License (CC-BY license).
} 
The (predominantly negative) stereotypes regarding late adulthood are still very much present in modern societies (e.g., Nelson, 2004), including Slovenia (Zupančič, Kavčič, \& Colnerič, 2011). Moreover, research showed that negative age (self-)stereotypes have detrimental effects on a variety of cognitive and physical outcomes in older adults, including memory and cognitive performance (Lamont, Swift, \& Abrams, 2015), functional health, and longevity (Levy, Slade, Kunkel, \& Kasl, 2002). Thus, it is important to obtain empirical scientific knowledge on actual characteristics and activities of older adults. Time-use following retirement has been the subject of several studies in larger western countries (e.g., Gauthier \& Smeeding, 2003; McKenna, Broome, \& Liddle, 2007; Oerlemans, Bakker, \& Veenhoven, 2011; Tadic, Oerlemans, Bakker, \& Veenhoven, 2013), but seldom in Slovenia (however, see Petrič \& Zupančič [2012, 2016] for analyses of leisure activities in late adulthood). Some of the previous studies investigated the role of involvement in specific activities in well-being of older adults, but they considered wellbeing rather narrowly as affective or cognitive aspects of hedonic well-being only (but see Petrič, 2014). Therefore, the aim of our study was to investigate how activities contribute to well-being, measured more comprehensively as satisfaction with the day, and global emotional, psychological and social well-being, sometimes labelled also hedonic (emotional well-being) and eudaimonic (psychological and social wellbeing) happiness (Maltby, Day, \& Barber, 2005). Moreover, the present study aimed to advance the knowledge on the role of activities in older adults' well-being by including tangible measures of activities (involvement and time-spent) as well as subjective experiences of these activities.

\section{Well-being in late adulthood}

Subjective well-being (SWB) refers to people's evaluation of their lives in various realms from their own perspective (Diener, Kasebir, \& Lucas, 2008). It reflects a core aspect of quality of life throughout the lifespan, including late adulthood (Ferring \& Boll, 2010). In contemporary psychology, SWB was first conceptualized as satisfaction with life (overall or in diverse specific domains) and as a predominance of positive over negative emotionality (e.g., Diener, 1984). This aspect of well-being is referred to as emotional or hedonic component of SWB. Later, Ryff (1989) noted that experiences of satisfaction, happiness, enjoyment etc. could not fully capture the entire scope of people's experiences that contribute to the quality of their lives. Individuals' experiences of selfactualization, meaning of life, having positive relations with close others, being autonomous and competent in coping with everyday situations are also important components of wellbeing. These aspects describe psychological well-being, an intrapersonal eudaimonic component of SWB. Finally, Keyes (1998) added an interpersonal eudaimonic component of SWB, i.e. social well-being, referring to individuals' perceptions of their integration and functioning within wider community and society. Keyes' model (2002) incorporated both hedonic and eudaimonic aspects of well-being, thus providing suitable criterion variables for our study. In this model, emotional well-being component is considered an indicator of hedonic well-being, while psychological and social well- being are indicators of positive functioning or eudaimonic well-being.

Subjective well-being is associated with a wide array of positive outcomes, including good social relationships, superior work performance, higher incomes, more community involvement, and better health (for overview see Lyubomirsky, King, \& Diener, 2005). Few studies focused on effects of well-being in older adults specifically. These studies suggest that indicators of well-being in late adulthood are associated with positive outcomes, such as better physical and mental health, longevity, and lower mortality (e.g., Achat, Kawachi, Spiro, DeMolles, \& Sparrow, 2000). Nevertheless, how SWB is achieved in late adulthood remains an open research question (Ferring \& Boll, 2010). One of the potential sources of SWB in late adulthood are daily activities of older adults.

\section{Associations between well-being and daily activities in late adulthood}

The role of daily activities in older adults' well-being and successful aging has been recognized in theoretical and empirical work for quite some time. The activity theory (Lemon, Bengtson, \& Peterson, 1972) states that happiness largely depends on what people do and how active they are in their daily life. Moreover, Rowe and Kahn (1987) posited that successful aging includes three key aspects: (i) low probability of disease and disease-related disability, (ii) high cognitive and physical functioning, and (iii) active lifestyle, defined as maintenance of close relationships with others and involvement in meaningful activities (Rowe \& Kahn, 1998). Empirically, Lyubomirsky, Sheldon, and Schkade (2005) showed that up to $40 \%$ of variance in well-being is not explained by circumstances and dispositions, suggesting a possible substantial link between happiness and activities people engage in (Ferring \& Boll, 2010; Herero \& Extremera 2010).

Indeed, previous research showed that older adults are happier when they are more active (e.g., Herzog, Franks, Markus, \& Holmberg, 1998) with higher activity levels being related to happiness even longitudinally (Menec, 2003). Moreover, an increase in activity seems to be related to an increase in positive affect and a decrease in negative affect (Pushkar et al., 2010). In addition to a general activity level, involvement in specific activities contributes to individuals' well-being (e.g., Menec, 2003; Petrič, 2014), because it may satisfy various personal needs (Ryan \& Deci, 2000). Specifically, "social activities" satisfy people's need for relatedness; "physical activities" contribute to well-being physiologically and psychologically by supporting a sense of mastery; "cognitive activities" meet the need for competence or curiosity; and "household activities" have a detrimental effect on well-being (for an overview see Oerlemans et al., 2011). Yet, there is considerable variation between people not only in the amount and type of activity they engage in, but also in their subjective experiences of specific activities (e.g., Reis, Sheldon, Gable, Roscoe, \& Ryan, 2000). Some of the previous studies (Oerlemans et al. 2011; Tadic et al., 2013) analyzed the variation in experiences across activities of older adults, but they focused on momentary happiness only. However, people across adulthood vary in their positive and negative feelings as well as non-hedonic experiences during specific activities (White \& 
Dolan, 2009). Thus, the present study aimed to explore the level of hedonia (presence of positive emotionality and absence of negative emotionality) and eudaimonia (meaningfulness, usefulness of activities) experienced during various activities in late adulthood and the role of these experiences in older adults' daily and global well-being.

\section{Measuring well-being and daily activities}

Most commonly, SWB is measured as a global evaluation of one's quality of life. However, memory of one's moods could be distorted due to overestimation of some and underestimation of other feelings (Diener \& Tay, 2014). Memory biases are eliminated or minimized by proximity of the recall to the experience. One of the frequently used methods focusing on recent experiences of well-being is the Experience Sampling Method (ESM) involving a use of an electronic diary (via smart phones, beepers, or tablets) that beeps at random times and asks the participants to indicate activities and feelings or thoughts at that time. This method is rather quick and provides lots of data, but may be less suitable for older adults as they may be less familiar and skilled with the technology required (Ferring \& Boll, 2010). The other method is the Day Reconstruction Method (DRM; Kahneman, Krueger, Schkade, Schwarz, \& Stone, 2004a, b), which requires the respondents to fill out a diary about their activities throughout the previous day and rate their experiences during these activities. It imposes fewer burdens on the participants than the ESM, but by evoking the context of the previous day, it elicits specific and recent memories and thereby reduces memory errors and biases. Moreover, it provides an assessment of momentary experiences during continuous episodes throughout a day, rather than a sample of discrete, isolated moments (Tadic et al., 2013). DRM quite accurately captures daily fluctuations in well-being experienced as indicated by congruence between the DRM and ESM reports (e.g., Kahneman et al., 2004b).

\section{The present study}

The aim of this study was threefold. First, using the Day reconstruction method we planned to describe typical days of older adults in Slovenia; i.e. how much time they spend in various activities. Based on previous studies (e.g., Gauthier \& Smeeding, 2003), older adults were expected to spend most of their time in personal activities (e.g., bathing, dressing), passive leisure activities (e.g., relaxing, watching TV), housework, and social activities. Second, we were interested in older adults' subjective experiences of activities throughout their day, i.e., experienced hedonia and eudaimonia during various activities. Finally, we explored how older adults' participation and experience in various activities relate to their daily and global emotional, psychological, and social well-being. Based on past research (e.g., Menec, 2003; Petrič, 2014) and conceptualization of the three components of well-being (e.g., Keyes, 2002), we presumed that (i) socializing and leisure (physical) activities positively relate to daily and global emotional well-being; (ii) social, educational, volunteer and work-related activities to psychological well-being; (iii) socializing, volunteering, work activities and taking care of children to social well-being. Furthermore, we expected that the participants' well-being may be associated with what they do but even more so with their subjective perceptions of their daily activities.

\section{Method}

\section{Participants}

The present study included 84 older adults $(61 \%$ women and $39 \%$ men), aged from 65 to 91 years $(M=73, S D=6.4$ years). A vast majority was retired $(95 \%)$, while this status remained undefined for four participants. Regarding participants' education, $48 \%$ had finished primary education, $38 \%$ secondary education, and $14 \%$ finished some form of tertiary education, which is very similar to the population data (SURS, 2016). With regard to marital status, $61 \%$ of participants were married or living together with their partner, one was in a long-term relationship and $39 \%$ were single or widowed. All participants except one had at least one child.

\section{Instruments}

Day Reconstruction Method (DRM). An extended online version of the DRM (Kahneman et al., 2004a, b; White \& Dolan, 2009) was used to measure time-use and experiences of different activities. DRM asks the respondents to complete a "diary" of their previous day. First, participants divided their waking time during the past day into personally meaningful episodes (e.g., grandchildren visited). For each episode, they provided the start and the end time, and selected what they were doing from a given list of 26 activities (e.g., eating; if they chose more than one activity for a specific episode, they were asked to name the predominant activity of that episode). For each episode, they also assessed the level of six indicators of hedonia (happy, content/relaxed, and reversed nervous/anxious, frustrated, impatient, sad/depressed) and six indicators of eudaimonia (feeling focused, engaged, competent/able, perceiving activities as worthwhile and meaningful, useful to other people, helping achieve important goals). These ratings were averaged into mean hedonia (with ratings of negative feelings reversed) and eudaimonia scores for each episode. Finally, the participants reported how satisfied they were with the entire past day on a 7-point scale ranging from very unsatisfied (-3) to very satisfied (3), and how typical this day was on a 7 -point scale ranging from much worse $(-3)$ to fairly typical (0) to much better (3).

Mental Health Continuum - Long Form (MHC-LF). The MHC-LF (Keyes, 2009) was used to measure the three components of well-being: emotional, psychological and social. The emotional well-being is measured by six items tapping positive affect (Mroczek and Kolarz, 1998) rated on a 5-point scale ( 1 - none, 5 - all of the time) and a single item depicting life satisfaction rated on a scale from 0 (the worst possible life overall) to 10 (the best possible life overall). Psychological well-being is measured by 18 items (Ryff, 1989) and social well-being by 15 items (Keyes, 1998), all measured on a 7-point Likert scale ranging from strongly agree to strongly disagree. Due to different rating scales, all scale scores were calculated as mean z-values of item scores. The 
three-factor structure of the English version of the MHC-LF has been confirmed (e.g., Robitschek \& Keyes, 2009) and the three well-being scales were found to have satisfactory internal consistency with alphas over .80 (Keyes, 1998, 2002; Ryff $\&$ Keyes, 1995). The Slovene version of the MHC-LF has not been validated previously. Because the present sample was rather small and because the three scales are actually distinct, separately designed questionnaires, we examined the factor structure of each scale separately. We performed principal component analyses and inspected the scree plots. The analysis of the seven emotional well-being items suggested a one-factor solution (eigen values: 4.00, 1.05, 0.67, 0.53, 0.39, $0.26,0.13$ ), explaining $57 \%$ of variance; the analysis of the 18 psychological well-being items suggested a one- or possibly a three-factor solution (eigen values: 4.81, 2.22, 1.82, 1.24, 1.13, $0.94,0.82,0.80$ ), explaining $27 \%$ or $50 \%$ of variance, respectively; and the analysis of the 15 social well-being items suggested a one- or possibly a four-factor solution (eigen values: $3.88,2.06,1.61,1.29,1.03,0.96,0.81,0.67,0.55 \ldots)$, explaining $26 \%$ and $50 \%$ of variance, respectively. In line with studies of MHC-LF with much bigger samples, we opted for one-factor solutions for each of the three scales. In the present study, the three scales showed satisfactory internal consistency with alpha coefficients .87 for emotional well-being, .87 for psychological well-being, and .77 for social well-being.

\section{Procedure}

The participants, aged 65 years or more (no upper age limit was defined), were recruited using a snowball method starting with personal contacts of researchers and their students. In order to ascertain the heterogeneity of the sample, the website was additionally promoted by different means such as press coverage and certain private websites. The participants filled-in the DRM and the MHC-LF on a website. As our aim was to get insight into a random day in the lives of older adults, we did not ask the participants to describe a certain day of the week but rather the day preceding the participation in the study. Most of them completed the survey independently, while some had help by previously trained students. The participation in the study was voluntary. At the beginning, the respondents were informed about the aims of the research and they gave an informed consent to participate. Then they provided general and demographic data and filled-in DRM, MHC-LF, and some additional scales not relevant for the present study. At the end, they were thanked and provided with an automatically generated feedback on their personal well-being. The data collection lasted approximately one year.

Table 1. Descriptive statistics for time spent (in minutes) in daily activities by all the participating older adults and those, who engaged in a specific activity

\begin{tabular}{|c|c|c|c|c|c|c|c|c|c|}
\hline \multirow[b]{2}{*}{ Activity } & \multicolumn{4}{|c|}{ All participants $(N=84)$} & \multicolumn{5}{|c|}{ Engaged participants } \\
\hline & Range & $M d n$ & $M$ & $S D$ & $N$ & Range & $M d n$ & $M$ & $S D$ \\
\hline Watching TV & $0-510$ & 120 & 133 & 117 & 61 & $40-510$ & 180 & 183 & 97 \\
\hline Socializing & $0-390$ & 60 & 83 & 98 & 47 & $30-390$ & 120 & 148 & 87 \\
\hline Cooking & $0-420$ & 60 & 82 & 95 & 54 & $30-420$ & 108 & 128 & 91 \\
\hline Eating & $0-420$ & 60 & 76 & 80 & 55 & $10-420$ & 120 & 116 & 72 \\
\hline Housework & $0-420$ & 0 & 67 & 104 & 34 & $60-420$ & 133 & 164 & 103 \\
\hline Relaxing & $0-300$ & 0 & 51 & 78 & 34 & $30-300$ & 120 & 125 & 75 \\
\hline Reading & $0-480$ & 0 & 49 & 102 & 24 & $30-480$ & 143 & 172 & 123 \\
\hline Getting ready & $0-300$ & 8 & 35 & 52 & 43 & $5-300$ & 60 & 68 & 55 \\
\hline Work & $0-455$ & 0 & 34 & 97 & 13 & $30-455$ & 240 & 218 & 149 \\
\hline Shopping & $0-300$ & 0 & 29 & 63 & 22 & $20-300$ & 90 & 110 & 81 \\
\hline Using the internet & $0-420$ & 0 & 22 & 77 & 9 & $30-420$ & 180 & 209 & 131 \\
\hline Walking & $0-360$ & 0 & 18 & 50 & 15 & $45-360$ & 60 & 99 & 77 \\
\hline Other activities & $0-240$ & 0 & 16 & 49 & 11 & $30-240$ & 120 & 120 & 80 \\
\hline Gardening & $0-240$ & 0 & 10 & 44 & 6 & $30-240$ & 150 & 145 & 90 \\
\hline Listening to music & $0-240$ & 0 & 8 & 38 & 5 & $45-240$ & 60 & 129 & 102 \\
\hline Enjoying nature & $0-235$ & 0 & 7 & 31 & 7 & $5-235$ & 60 & 86 & 74 \\
\hline Religious activity & $0-240$ & 0 & 7 & 30 & 6 & $45-240$ & 60 & 93 & 74 \\
\hline Driving & $0-120$ & 0 & 4 & 19 & 4 & $30-120$ & 90 & 83 & 38 \\
\hline Volunteer work & $0-180$ & 0 & 4 & 23 & 2 & $120-180$ & 150 & 150 & 42 \\
\hline Sport/exercise & $0-90$ & 0 & 2 & 12 & 3 & $30-90$ & 60 & 60 & 30 \\
\hline Getting children ready & $0-120$ & 0 & 2 & 14 & 3 & $15-120$ & 35 & 57 & 56 \\
\hline Mind-wandering & $0-60$ & 0 & 2 & 10 & 3 & $30-60$ & 60 & 50 & 17 \\
\hline Cycling & $0-60$ & 0 & 1 & 7 & 2 & $30-60$ & 45 & 45 & 21 \\
\hline Taking children to/from school & $0-60$ & 0 & 1 & 7 & 1 & $60-60$ & 60 & 60 & 0 \\
\hline Intimate relations & $0-60$ & 0 & 1 & 7 & 1 & $60-60$ & 60 & 60 & 0 \\
\hline Travelling by bus/train & 0 & 0 & 0 & 0 & 0 & 0 & 0 & 0 & 0 \\
\hline Going to/from work & 0 & 0 & 0 & 0 & 0 & 0 & 0 & 0 & 0 \\
\hline
\end{tabular}




\section{Results}

Overall, the participants assessed their yesterday as a rather typical day $(M=0.59 ; S D=0.83)$. They reported on daily activities lasting jointly on average almost 14 hours $(M$ $=820 ; S D=254$ minutes). They divided this time into 3 to 16 episodes $(M=8 ; S D=3)$.

\section{Time spent in different daily activities}

Table 1 shows how much time the participating older adults spent doing different daily activities. Descriptive statistics are presented separately for all participants and for those who actually engaged in a certain activity. Generally, the most time was spent in routine activities, such as cooking, eating, doing household chores, and getting ready (washing, getting dressed, etc.), and rather passive leisure activities, such as watching TV, relaxing, reading, and using the internet. Quite a lot of time was dedicated also to socializing with friends, work, and walking. On average, the participants devoted little time to driving, volunteer work, sport/exercise and cycling, having intimate relations, and mind-wandering. However, only a small proportion of participants engaged in these activities and those who did actually spent quite some time involved in them. For example, six participants spent time gardening during their previous day but they were gardening from 30 minutes up to four hours. A non-negligible proportion of participating older adults (13 out of 84) still had an at least part time job during their retirement. Eleven out of 84 respondents also reported engaging in activities not on a list and lasting from half an hour to two hours. These other activities were rare and included a range of various activities, such as playing an instrument, making plans, waiting, taking care of animals, driving a boat, creating gifts, visiting graves, attending cultural events.

\section{Subjective experiences during daily activities}

For each of the activities reported, participating older adults evaluated their experienced hedonia and eudaimonia. Figure 1 presents average hedonia and eudaimonia scores for different activities. Please note that certain average evaluations were based on a rather small number of reports provided by participants who engaged in less frequent activities during their previous day.

The average hedonia and eudaimonia experienced by the participating older adults varied considerably across activities. Although involved in by a very small number of the

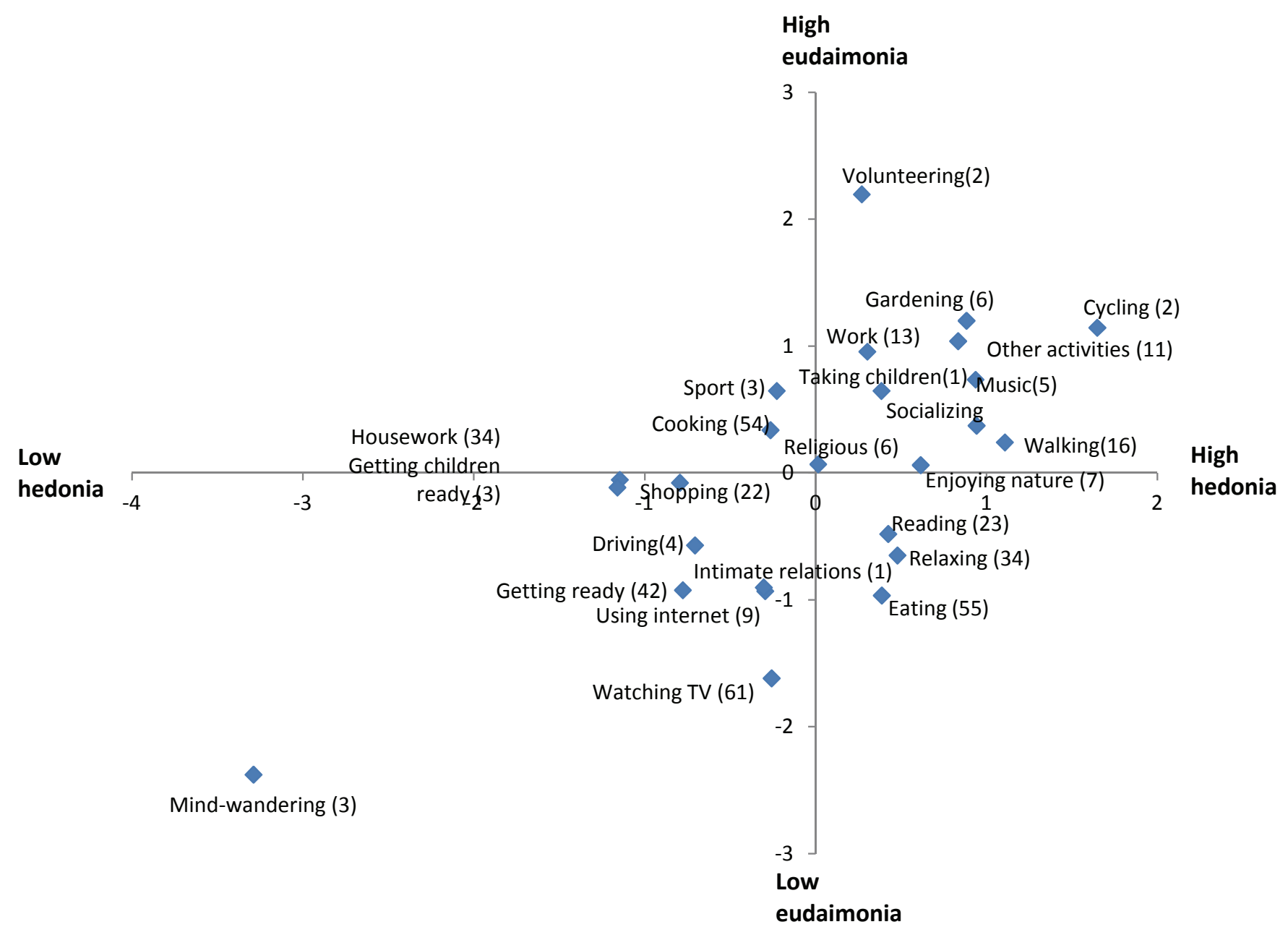

Figure 1. Mean subjective hedonia (x-axis) and eudaimonia (y-axis) experienced during different activities (in z-values). Number of participants engaging in a certain activity is presented in the brackets. 
respondents, mind-wandering seems to be experienced as extremely meaningless and also unpleasant pastime, while volunteering appears to be perceived as extremely meaningful, though only slightly above average on hedonia. Activities that were perceived as pleasant as well as meaningful include cycling and walking (other sport and exercise activities were perceived as less pleasant), gardening, listening to music, socializing with friends, and work. Activities that are rather necessary, such as housework, cooking, driving, and getting ready were perceived as less enjoyable, though they differed with regard to their meaningfulness. In contrast to cooking, experienced as somewhat useful/meaningful but not very enjoyable, eating was perceived as somewhat enjoyable but rather low on eudaimonia. Interestingly, watching TV and using the internet were perceived as very meaningless and also not very enjoyable. Further, reading and relaxing were experienced as quite pleasant though not very meaningful or useful.

\section{Daily activities and well-being}

Our next aim was to investigate associations of older adults' daily (satisfaction with that day) and global well-being (overall emotional, psychological and social well-being) with the activities they engaged in. We investigated these associations in two sets of analyses - comparisons of group means and correlations. First, $t$-tests for independent samples were used to estimate the differences in daily and global well-being between participants who engaged in a certain activity and those who didn't. The effect size was estimated by Hedges' $g$. As only a few participants reported on engaging in some of the activities, we focused our attention on activities reported by at least five respondents.
Engaging vs. not engaging in various activities during the previous day had no statistically significant effect on respondents' daily well-being. The same was established for measures of global well-being with a few exceptions. Older adults who spent an episode getting ready evaluated their social well-being $(N=41, M z=-0.12, S D z=0.49)$ as moderately lower than those who did not engage in this activity $(N$ $=40, M z=0.12, S D z=0.46$ ) or at least didn't see this activity as predominant in one of their daily episodes $(t(79)=-2.34$, $p<.05, g=0.52)$. Compared to the respondents who engaged in work $(N=13, M z=0.27, S D z=0.53)$, those not working $(N$ $=68, M z=-0.05, S D z=0.47)$ had moderately lower psychological well-being $(t(79)=2.21, p<.05, g=0.67)$. Watching TV had a moderate negative effect $(t(79)=-2.12, p<.05, g=$ $0.52)$ on emotional well-being with older adults who watched TV the previous day $(N=59, M z=-0.10, S D z=0.72)$ evaluating their emotional well-being lower than those who didn't watch TV $(N=22, M z=0.28, S D z=0.75)$.

Second, we calculated the correlations of daily and global well-being measures with time spent in different activities. Only activities with $N$ over 15 were included. All the correlations were small and statistically insignificant with the exception of a moderate positive correlation between time spent shopping and social well-being $(r=.44, p<.05, N=$ $21)$, and a moderate positive correlations between time spent socializing with friends $(N=34)$ and satisfaction with the day $(r=.40, p<.05)$, emotional well-being $(r=.44, p<.01)$, and psychological well-being $(r=.35, p<.05)$.

Older adult's daily or global well-being could be associated not just with engagement in certain activities but also with subjective experiences of that activity. To investigate this assumption, we calculated Pearson correlation coefficients between hedonia and eudaimonia experienced dur-

Table 2. Correlations of perceived hedonia and eudaimonia during various activities with daily and global well-being

\begin{tabular}{|c|c|c|c|c|c|}
\hline Activity & Experiences & $\begin{array}{l}\text { Satisfaction } \\
\text { with the day }\end{array}$ & $\begin{array}{l}\text { Emotional } \\
\text { well-being }\end{array}$ & $\begin{array}{l}\text { Psychological } \\
\text { well-being }\end{array}$ & $\begin{array}{c}\text { Social } \\
\text { well-being }\end{array}$ \\
\hline \multirow{2}{*}{$\begin{array}{l}\text { Getting ready } \\
(N=41)\end{array}$} & Hedonia & .16 & $.33^{*}$ & .16 & .21 \\
\hline & Eudaimonia & .11 & .24 & .29 & .24 \\
\hline \multirow{2}{*}{$\begin{array}{l}\text { Cooking } \\
(N=50)\end{array}$} & Hedonia & $.38^{* *}$ & .22 & $.55^{* * *}$ & .23 \\
\hline & Eudaimonia & $.31^{*}$ & .26 & $.34^{*}$ & $.32^{*}$ \\
\hline \multirow{2}{*}{$\begin{array}{l}\text { Eating } \\
(N=53)\end{array}$} & Hedonia & $.40^{* *}$ & $.36^{* *}$ & $.49^{* *}$ & $.36^{* *}$ \\
\hline & Eudaimonia & .25 & .27 & $.40^{* *}$ & .16 \\
\hline \multirow{2}{*}{$\begin{array}{l}\text { Housework } \\
(N=33)\end{array}$} & Hedonia & .22 & .22 & .32 & .16 \\
\hline & Eudaimonia & $.37^{*}$ & .00 & .26 & .18 \\
\hline \multirow{2}{*}{$\begin{array}{l}\text { Shopping } \\
(N=21)\end{array}$} & Hedonia & .23 & .04 & -.16 & .18 \\
\hline & Eudaimonia & .26 & .13 & .07 & .17 \\
\hline \multirow{2}{*}{$\begin{array}{l}\text { Relaxing } \\
(N=33)\end{array}$} & Hedonia & .33 & .26 & $.48^{* *}$ & $.38^{*}$ \\
\hline & Eudaimonia & .23 & .17 & .22 & .32 \\
\hline \multirow{2}{*}{$\begin{array}{l}\text { Watching TV } \\
(N=59)\end{array}$} & Hedonia & $.35^{* *}$ & .16 & $.32^{*}$ & .10 \\
\hline & Eudaimonia & .11 & .21 & .14 & .14 \\
\hline \multirow{2}{*}{$\begin{array}{l}\text { Reading } \\
(N=22)\end{array}$} & Hedonia & .34 & .09 & $.44^{*}$ & .09 \\
\hline & Eudaimonia & .18 & .33 & $.42^{*}$ & .29 \\
\hline \multirow{2}{*}{$\begin{array}{l}\text { Socializing } \\
(N=46)\end{array}$} & Hedonia & $.31^{*}$ & -.16 & .24 & .03 \\
\hline & Eudaimonia & -.03 & .03 & .18 & .13 \\
\hline \multirow{2}{*}{$\begin{array}{l}\text { Across the day } \\
(N=81)\end{array}$} & Hedonia & $.35^{* *}$ & $.36^{* *}$ & $.52^{* * *}$ & $.29^{* *}$ \\
\hline & Eudaimonia & .19 & $.23^{*}$ & $.32^{* *}$ & $.27^{*}$ \\
\hline
\end{tabular}

Note. $N \mathrm{~s}$ in this table may be different from those presented in Table 2 or Figure 1 due to some missing data for the well-being measures. ${ }^{*} p<.05,{ }^{* *} p<.01,{ }^{* * *} p<.001$ 
ing specific activities (engaged in by at least 15 participants) and well-being measures. Furthermore, we estimated associations between well-being measures and individuals' mean hedonia and eudaimonia scores across all activities in the selected day. Overall, the results presented in Table 2 indicate positive associations of experienced hedonia (moderate) and eudaimonia (modest) with daily and global well-being. Eyeball inspection of the correlations indicates the highest associations between well-being and perceptions of rather routine activities (such as cooking, eating and relaxing).

\section{Discussion}

The present study investigated time-use and its associations with well-being in Slovene older adults. Time-use was measured by DRM (Kahneman et al., 2004a, b), designed to capture type of activities engaged in over a day and subjective experiences of these activities. Overall, our results highlight the importance of engagement in activities subjectively perceived as pleasant and/or meaningful for daily and global well-being in late adulthood.

\section{Duration and experiences of various activities}

Previous studies used various methodological approaches to measure time-use and employed diverse activity categories, thus the results are not easily comparable. Keeping this in mind, our results regarding older adults' time spent in various activities are similar to findings in different countries across Europe, Australia, and USA (Eurostat, 2003; Gauthier \& Smeeding, 2003; McKenna et al., 2007). Nevertheless, a vast variability in time-use across individuals should be noted.

As expected, Slovene older adults seem to spend most of their time engaged in routine activities, such as cooking, eating, doing housework and getting ready, and in relatively passive leisure activities, such as watching television, reading and relaxing. Routine household activities tended to be characterized by low hedonia, which could be due to the unavoidable nature of these activities (Oerlemans et al., 2011), making them less enjoyable. Reading and relaxing were perceived as rather pleasant, while older adults didn't attach much meaning or usefulness to them. However, a longitudinal DRM study by Oerlemans et al. (2011) showed that restful, passive activities enhance the effect of more effortful activities on well-being in older adults as they enable them to recover. Thus, restful activities may well be considered useful and beneficial if balanced with effortful activities.

On average, our participants also spent quite a big part of their day watching TV, which was accompanied by very low eudamonia and below-average hedonia. The obtained low eudaimonia experienced during TV watching is consistent with reports by German adults, aged 16 to 80 years (White \& Dolan, 2009), but the participants in this German study perceived this activity as somewhat more pleasant than the Slovene older adults. The difference between the results of the two studies could be due to the age differences between samples. Namely, an extensive U.S. study revealed that older adults spent up to threefold more time watching TV than younger adults, but the older individuals enjoyed it less than the younger ones (Depp, Schkade, Thomson, \& Jeste, 2010). Similar levels of hedonia and eudaimonia as perceived during watching TV were observed during episodes spent using the internet but this activity was much less common in our participants.

Contrary to an earlier myth on unproductivity of older adults (e.g., Butler, 1987), 15\% of the participants in our study reported engaging in paid work for up to almost eight hours a day. On average, our participants spent working approximately half an hour during their previous day, a result similar to findings of time-use surveys in 13 countries across Europe (Eurostat, 2003). Moreover, work episodes were characterized by high eudamonia and somewhat elevated hedonia, suggesting that engaging in work after retirement could be a source of experiences of competence, usefulness and meaning, and positive affect. Similar could be said for volunteer work, which was marked by extremely high eudaimonia combined with slightly above-average hedonia. However, only two participants reported on this activity and caution is needed when generalizing this finding. Nevertheless, the obtained pattern of experiences during volunteer work is consistent with findings of a larger German study across adulthood (White \& Dolan, 2009).

Among frequent activities, socializing with friends was marked by a prevalence of positive over negative affect accompanied by feelings of focus, engagement, competence, meaning, and usefulness. This finding is in line with the notion that the so-called social activities contribute to individuals' feelings of connectedness, recognition, and value (Folkman, 1997), thus satisfying their need for relatedness (Ryan \& Deci, 2000). Accordingly, it is rather encouraging that our participants spent on average two and a half hours during their previous day socializing with their friends.

Elevated levels of hedonia and (to a various extent) eudaimonia were experienced by participating older adults also during activities requiring physical effort: gardening, cycling and walking. Physical activities may be associated with positive emotionality because they can contribute to a sense of mastery and feeling good about oneself (Folkman, 1997), as well as stimulate physiological processes that promote wellbeing (Wankel \& Berger, 1990).

\section{Daily activities and well-being}

The present study also investigated associations of spending time in various activities with older adults' emotional, psychological, and social well-being. Generally, the effects of engaging vs. not engaging in specific activities on well-being measures were small, as were also the correlations between time spent in a certain activity and well-being. Nevertheless, engaging in work had a moderate positive effect on older adults' psychological well-being, suggesting that working in older adulthood is not only a source of momentary feelings of positive emotionality, usefulness and meaning, but is also associated with global evaluations of one's functioning as purposeful, autonomous, competent, and advancing, which are all components of psychological well-being (Ryff, 1989). Correspondingly, the association between engagement 
in paid work and life satisfaction (a component of emotional well-being) was found in English older adults (McMunn, Nazroo, Wahrendorf, Breeze, \& Zaninotto, 2009), though our study suggests that work may be especially relevant for older adults' psychological well-being. Further, time spent watching TV, which was perceived as very meaningless and rather unpleasant, showed negative associations with global emotional well-being. This finding is consistent with research by Depp et al. (2010) revealing associations between TV watching and lower life satisfaction. Of course, we should keep in mind that the present study was cross-sectional and any conclusions regarding causal explanations are not possible. For example, watching TV could lead to less favourable momentary and global well-being, but it is also possible that older adults prone to (momentarily or globally) experiencing lower levels of positive emotionality tend to watch TV more commonly than those with higher emotional well-being.

In addition to time spent in various activities, the subjective experiences of these activities could be related to older adults' well-being. Indeed, perceived hedonia and (to a somewhat lower extent) eudaimonia during various common activities in our study tended to be positively associated with daily well-being and the three components of global well-being. This is also true for routine and passive leisure activities. For example, despite the negative effect of watching TV (vs. not) on emotional well-being, higher levels of hedonia and eudaimonia experienced by those who did watch TV during their yesterday tended to be associated with higher satisfaction with that day and global well-being. Similarly, even though routine activities like cooking, eating, housework, and getting ready were perceived quite unfavourably, experiences of relatively higher levels of hedonia and eudaimonia during these activities related to higher levels of older adults' daily and/or global well-being. The associations revealed could emerge because (i) perceiving various activities as more pleasant and meaningful may lead to higher well-being (e.g., Lyubomirsky, King, \& Diener, 2005); (ii) higher levels of well-being might shape the subjective perceptions of diverse activities as rather pleasant and meaningful (Grimm, Kemp, \& Jose, 2015); (iii) a third common factor (e.g., personality traits; Sun, Kaufman, \& Smillie, 2018) affects perceived hedonia and eudaimonia on a momentary and on a global level.

\section{Conclusions}

In their overview of the current state of knowledge on subjective well-being in older adults, Ferring and Boll (2010) raised the questions of insufficiently broad measurement of well-being, limited age range of participating older adults, and a lack of knowledge on factors of well-being in late adulthood. The present study aspired to overcome these gaps by including measures of daily and global well-being, with the later encompassing emotional, psychological, and social wellbeing. Moreover, a wide age range across late adulthood was covered. With regard to the factors of SWB in older adults, engagement and subjective perceptions of various activities throughout one day were investigated and shown to be associated with all aspects of SWB.
Certain shortcomings of our study should be mentioned. The study included a rather small sample of Slovene older adults, limiting the generalizability of the results and hindering the investigation of relatively rare activities. Next, the use of DRM was quite lengthy which could lead to a loss of attention. However, DRM was selected as it is (i) less susceptible to biases and inaccuracies in recall of moods (due to eliciting specific and recent memories) than classic questionnaire measures, and (ii) more suitable for older adults than ESM as it may reduce the burden for the respondents, minimize the disruption of their normal everyday life and tap experiences over a full day (Heo, Lee, Kim, \& Chun, 2012). In addition, even though self-report measures could pose some challenges for old and very old adults, researchers should resist the temptation to obtain these reports from older adults' family members or caregivers as the consensus between self- and otherreports of well-being is rather low (Ferring \& Boll, 2010). Still, the data was collected on-line, which could have contributed to the self-selection of the participating older adults. However, it should be noted that the study also included older adults who might have been less familiar with computers but participated with the help of previously trained students.

Future studies with larger representative samples of older adults are needed to enable the investigation of associations between global well-being and various specific activities (engagement and subjective experiences of these activities) and examination of possible differences between young-old and old-old adults. Further, a longitudinal design would allow the examination of the direction of these associations. The role of other possible moderating variables also remains to be investigated; e.g., personality traits could moderate the effects of specific activities on person's momentary experiences and global well-being (e.g., Oerlemans \& Bakker, 2014); individuals' perceptions of various activities could depend on their orientations to happiness (Peterson, Park, \& Seligman, 2005).

To sum up, our study showed that older adults vary substantially in how they spend their time and how they subjectively perceive the activities they engage in. The results highlight that while engagement in certain activities may be associated with well-being, it is the subjective experience of these activities that probably plays the crucial role in older adults' emotional, psychological, and social well-being. With regard to practical implications for professional workers and policy makers, our results highlight the importance of older adults' engagement in activities characterized by high levels of hedonia and eudaimonia. On the one hand, certain activities (e.g., socializing with friends, physically active leisure time, and work) are more likely to be associated with favourable momentary experiences and/or global well-being. While older adulthood is generally a period of withdrawal from the labour market, previous research suggests that non-paid work that is perceived as adequately rewarded (e.g., volunteer work) may also be associated with elevated well-being (McMunn et al., 2009). On the other hand, it is the subjective perception of a certain activity that matters most. Thus, older adults should be encouraged to engage in activities that they subjectively find enjoyable and meaningful and/or try to find some joy 
and purpose even in routine activities. Previous studies provided extensive evidence on links between positive emotions and physical health in older adults (for an overview see Ong, Mroczek, \& Riffin, 2011). Our study extends these findings to the domain of mental health as they showed that momentarily experienced hedonia was especially associated with daily and global well-being; activities that provide a source of positive emotions should therefore be encouraged.

\section{References}

Achat, H., Kawachi, I., Spiro, A., DeMolles, D. A., \& Sparrow, D. (2000). Optimism and depression as predictors of physical and mental health functioning: The Normative Aging Study. Annals of Behavioral Medicine, 22(2), 127-130.

Butler, R. N. (1987). Ageism. In G. L. Maddox (Ed.), The encyclopedia of aging (pp. 38-39). New York, NY, USA: Springer.

Depp, C. A., Schkade, D. A., Thompson, W. K., \& Jeste, D. V. (2010). Age, affective experience, and television use. American Journal of Preventive Medicine, 39(2), 173-178.

Diener, E. (1984). Subjective well-being. Psychological Bulletin, 95, 542-575.

Diener, E., Kesebir, P., \& Lucas, R. (2008). Benefits of accounts of well-being-for societies and for psychological science. Applied Psychology, 57(s1), 37-53.

Diener, E., \& Tay, L. (2014). Review of The Day Reconstruction Method (DRM). Social Indicators Research, 116(1), 255-267.

Eurostat (2003). Time use at different stages of life: Results from 13 European countries. Luxembourg: Office for Official Publications of the European Communities. Retrieved from http://ec.europa.eu/eurostat/ documents/3888793/5817325/KS-CC-03-001-EN.PDF/ 75b40b96-710d-4e04-b13b-739561ef3a4b

Ferring, D., \& Boll, T. (2010). Subjective well-being in older adults: Current state and gaps of research. In L. Bovenberg, A. van Soest, \& A. Zaidi (Eds.), Ageing, health and pensions in Europe (pp. 173-212). Hampshire, UK: Palgrave Macmillan.

Folkman, S. (1997). Positive psychological states and coping with severe stress. Social Science \& Medicine, 45, 1207-1221.

Gauthier, A. H., \& Smeeding, T. M. (2003). Time use at older ages: Cross-national differences. Research on Aging, 25(3), 247-274.

Grimm, C., Kemp, S., \& Jose, P. E. (2015). Orientations to happiness and the experience of everyday activities. The Journal of Positive Psychology, 10(3), 207-218.

Heo, J., Lee, Y., Kim, B., \& Chun, S. (2012). Contribution of relaxation on the subjective well-being of older adults. Activities, Adaptation \& Aging, 36(1), 1-10.

Herero, V. G., \& Extremera, N. (2010). Daily life activities as mediators of the relationship between personality variables and subjective well-being among older adults. Personality and Individual Differences, 49, 124-129.
Herzog, A., Franks, M. M., Markus, H. R., \& Holmberg, D. (1998). Activities and well-being in older age: Effects of self-concept and educational attainment. Psychology and Aging, 13(2), 179-185.

Kahneman, D., Krueger, A. B., Schkade, D. A., Schwarz, N., \& Stone, A. A. (2004a). The Day Reconstruction Method (DRM): Instrument Documentation. Retrieved from http://www.academia.edu/download/39604078/ The_Day_Reconstruction_Method_drm_Inst201511024520-qpenzk.pdf

Kahneman, D., Krueger, A. B., Schkade, D. A., Schwarz, N., \& Stone, A. A. (2004b). A survey method for characterizing daily life experience: The Day Reconstruction Method. Science, 306(5702), 1776-1780.

Keyes, C. L. M. (1998). Social well-being. Social Psychology Quarterly, 121-140.

Keyes, C. L. M. (2002). The mental health continuum: From languishing to flourishing in life. Journal of Health and Social Behavior, 43, 207-222.

Keyes, C. L. M. (2009). Mental Health Continuum - Long Form. In J. Magyae-Moe (Ed.), Therapist's guide to positive psychological interventions (pp. 30-33). San Diego, CA, USA: Elsevier Academic Press.

Lamont, R. A., Swift, H. J., \& Abrams, D. (2015). A review and meta-analysis of age-based stereotype threat: Negative stereotypes, not facts, do the damage. Psychology and Aging, 30(1), 180-193.

Lemon, B. W., Bengtson, V. L., \& Peterson, J. A. (1972). An exploration of the activity theory of aging: Activity types and life satisfaction among in-movers to a retirement community. Journal of Gerontology, 27(4), 511-523.

Levy, B. R., Slade, M. D., Kunkel, S. R., \& Kasl, S.V. (2002). Longevity increased by positive self-perceptions of aging. Journal of Personality and Social Psychology, 83, 261-270.

Lyubomirsky, S., King, L., \& Diener, E. (2005). The benefits of frequent positive affect: Does happiness lead to success? Psychological Bulletin, 131(6), 803-855.

Lyubomirsky, S., Sheldon, K. M., \& Schkade, D. (2005). Pursuing happiness: The architecture of sustainable change. Review of General Psychology, 9(2), 111-131.

Maltby, J., Day, L., \& Barber, L. (2005). Forgiveness and happiness: The differing contexts of forgiveness using the distinction between hedonic and eudaimonic happiness. Journal of Happiness Studies, 6(1), 1-13.

McKenna, K., Broome, K., \& Liddle, J. (2007). What older people do: Time use and exploring the link between role participation and life satisfaction in people aged 65 years and over. Australian Occupational Therapy Journal, 54(4), 273-284.

McMunn, A., Nazroo, J., Wahrendorf, M., Breeze, E., \& Zaninotto, P. (2009). Participation in socially-productive activities, reciprocity and wellbeing in later life: Baseline results in England. Ageing \& Society, 29(5), 765-782.

Menec, V. H. (2003). The relation between everyday activities and successful aging: A 6-year longitudinal study. The Journals of Gerontology: Series B, 58(2), S74-S82. 
Mroczek, D. K., \& Kolarz, C. M. (1998). The effect of age on positive and negative affect: A developmental perspective on happiness. Journal of Personality and Social Psychology, 75, 1333-1349.

Nelson, T. D. (Ed.) (2004). Ageism: Stereotyping and prejudice against older persons. Massachusetts, MA: MIT Press.

Oerlemans, W. G., \& Bakker, A. B. (2014). Why extraverts are happier: A day reconstruction study. Journal of Research in Personality, 50, 11-22.

Oerlemans, W. G., Bakker, A. B., \& Veenhoven, R. (2011). Finding the key to happy aging: A day reconstruction study of happiness. The Journals of Gerontology: Series B: Psychological Sciences and Social Sciences, 66, 665-674.

Ong, A. D., Mroczek, D. K., \& Riffin, C. (2011). The health significance of positive emotions in adulthood and later life. Social and Personality Psychology Compass, 5(8), 538-551.

Peterson, C., Park, N., \& Seligman, M. E. (2005). Orientations to happiness and life satisfaction: The full life versus the empty life. Journal of Happiness Studies, 6(1), 25-41.

Petrič, M. (2014). Napovedniki Keyesovega modela duševnega zdravja pri starostnikih [Predictors of Keyes' model of mental health in older adults] (Unpublished doctoral dissertation). Faculty of Arts, University of Ljubljana, Ljubljana.

Petrič, M., \& Zupančič, M. (2012). Ukvarjanje s prostočasnimi dejavnostmi v pozni odraslosti [Occupation with leisure activity in late adulthood]. Good Quality of Old Age, 15(2), 13-27.

Petrič, M., \& Zupančič, M. (2016). Prostočasne dejavnosti in mladostno počutje starejših [Leisure activities and youthful feel-age in elderly adults]. Good Quality of Old Age, 19(3), 20-31.

Pushkar, D., Chaikelson, J., Conway, M., Etezadi, J., Giannopoulus, C., Li, K., \& Wrosch, C. (2010). Testing continuity and activity variables as predictors of positive and negative affect in retirement. Journals of Gerontology: Series B, 65(1), 42-49.

Reis, H. T., Sheldon, K. M., Gable, S., Roscoe, J., \& Ryan, R. M. (2000). Daily well-being: The role of autonomy, competence, and relatedness. Personality and Social Psychology Bulletin, 26, 419-435.

Robitschek, C., \& Keyes, C. L. (2009). Keyes's model of mental health with personal growth initiative as a parsimonious predictor. Journal of Counseling Psychology, 56, 321-329.

Rowe, J. W., \& Kahn, R. L. (1987). Human aging: Usual and successful. Science, 237, 143-149.

Rowe, J. W., \& Kahn, R. L. (1998). Successful aging. New York, NY, USA: Random House.

Ryan, R. M., \& Deci, E. L. (2000). Self-determination theory and the facilitation of intrinsic motivation, social development, and well-being. American Psychologist, 55, 68-78.

Ryff, C.D.(1989).Happiness is everything, or is it? Explorations on the meaning of psychological well-being. Journal of Personality and Social Psychology, 57(6), 1069-1081.
Ryff, C. D., \& Keyes, C. L. M. (1995). The structure of psychological well-being revisited. Journal of Personality and Social Psychology, 69, 719-727.

Sun, J., Kaufman, S. B., \& Smillie, L. D. (2018). Unique associations between big five personality aspects and multiple dimensions of well-being. Journal of Personality, $86(2), 158-172$.

SURS (2016). Population aged 15 years or more by education, age and sex, Slovenia, annually. Retrieved from http://pxweb.stat.si/pxweb/Dialog/varval.asp?ma $=05 \mathrm{G} 2002 \mathrm{E} \& \mathrm{ti}=\&$ path $=. . /$ Database $/$ Demographics $/ 05$ population/20_Socio-economicPopulation/01_05G20_ education/\&lang=1

Tadic, M., Oerlemans, W. G., Bakker, A. B., \& Veenhoven, R. (2013). Daily activities and happiness in later life: The role of work status. Journal of Happiness Studies, 14(5), 1507-1527.

Wankel, L. M., \& Berger, B. G. (1990). The psychological and social benefits of sport and physical activity. Journal of Leisure Research, 22, 167-182.

White, M. P., \& Dolan, P. (2009). Accounting for the richness of daily activities. Psychological Science, 20(8), 1000-1008.

Zupančič, M., Kavčič, T., \& Colnerič, B. (2011). Kakšne so predstave odraslih v Sloveniji o starosti in starejših osebah? [Representations of aging and elderly in Slovene adults]. Good Quality of Old Age, 14(3), 24-39. 